\title{
Supplementary Chromium(III) Propionate Complex Does Not Protect Against Insulin Resistance in High-Fat-Fed Rats
}

\author{
Ewelina Król • Zbigniew Krejpcio • Katarzyna Iwanik
}

Received: 8 December 2013 / Accepted: 16 December 2013 / Published online: 12 January 2014

(C) The Author(s) 2014. This article is published with open access at Springerlink.com

\begin{abstract}
Improper eating habits such as high-fat or highcarbohydrate diets are responsible for metabolic changes resulting in impaired glucose tolerance, hyperinsulinemia, insulin resistance, and ultimately diabetes. Although the essentiality of trivalent chromium for humans has been recently questioned by researchers, pharmacological dosages of this element can improve insulin sensitivity in experimental animals and diabetic subjects. The aim of the study was to assess the preventive potential of the supplementary chromium(III) propionate complex (CrProp) in rats fed a high-fat diet. The experiment was conducted on 32 male Wistar rats divided into four groups and fed the following diets: the control (C, AIN93G), high-fat diets (HF, $40 \%$ energy from fat), and a high-fat diet supplemented with CrProp at dosages of 10 and $50 \mathrm{mg} \mathrm{Cr} / \mathrm{kg}$ diet $(\mathrm{HF}+\mathrm{Cr} 10$ and $\mathrm{HF}+\mathrm{Cr} 50$, respectively). After 8 weeks, high-fat feeding led to an increased body mass, hyperinsulinemia, insulin resistance, a decreased serum urea concentration, accumulation of lipid droplets in hepatocytes, and increased renal Fe and splenic $\mathrm{Cu}$ contents. Supplementary CrProp in both dosages did not alleviate these changes but increased renal $\mathrm{Cr}$ content and normalized splenic $\mathrm{Cu}$ content in high-fat-fed rats. Supplementary CrProp does not prevent the development of insulin resistance in rats fed a high-fat diet.
\end{abstract}

Keywords Chromium(III) propionate complex · Insulin resistance $\cdot$ High-fat diet $\cdot$ Rats

E. Król $(\bowtie) \cdot$ Z. Krejpcio

Department of Human Nutrition and Hygiene, Poznan University of

Life Sciences, Wojska Polskiego 31, 60-624 Poznan, Poland

e-mail: ekrol@up.poznan.pl

K. Iwanik

Department of Clinical Pathology, Poznan University of Medical

Sciences, Przybyszewskiego 49, 60-355 Poznan, Poland

\section{Introduction}

According to the forecast of the International Diabetes Federation, in the year 2030, the number of diabetics is expected to rise to 552 million worldwide [1]. Studies have shown that insulin resistance, defined as an impaired responsiveness of the body to insulin, is a prediabetic stage associated with obesity, leading to type 2 diabetes [2]; thus, it is believed that early identification and treatment of individuals with prediabetes can delay the progression of full-blown diabetes and related complications [3].

Chromium(III) is a dietary component involved in glucose metabolism, and for over 50 years, it has been considered as an essential element for mammals, including humans. Chromium(III) has a documented role in carbohydrate, lipid, and protein metabolisms [4]. Trivalent chromium has been shown to lower oxidative stress and improve glucose and lipid metabolism; however, the mechanism of its action on the molecular level is not fully understood yet.

$\mathrm{Cr}$ (III) supplements have become very popular commercial dietary supplements worldwide, advertised for reducing body mass and improving blood glucose control, especially for diabetic subjects. However, most of these claims were not supported in well-controlled studies. Recently, the "essentiality" of chromium has been questioned due to its ubiquitous nature, very low dietary requirement [5], and a lack of a reliable marker [6].

The major doubt came from the results of a study performed in Vincent's laboratory [5]. The authors fed male Zucker lean rats the AIN-93G diet with no added chromium in the mineral mix component of the diet (low-Cr diet$16 \mu \mathrm{g} / \mathrm{kg})$, the standard AIN-93G diet $(1,135 \mu \mathrm{g} / \mathrm{kg})$, the standard AIN-93G diet supplemented with $200 \mu \mathrm{g} \mathrm{Cr} / \mathrm{kg}$ $(1,331 \mu \mathrm{g} / \mathrm{kg})$, or the standard AIN-93G diet supplemented with $1,000 \mu \mathrm{g} \mathrm{Cr} / \mathrm{kg}(2,080 \mu \mathrm{g} / \mathrm{kg})$ for 6 months. It turned out that the chromium content of the diet had no effect on body 
mass or food intake, and serum glucose levels in glucose tolerance or insulin tolerance tests. The studies revealed that a diet with as little chromium as reasonably possible had no effect on body composition, glucose metabolism, or insulin sensitivity compared with a chromium-"sufficient" diet. Based on these observations, the authors concluded that chromium can no longer be considered an essential element.

The history of biochemical and nutritional studies of $\mathrm{Cr}$ has been broadly reviewed by Vincent and Love [7] and will not be repeated in detail in this article.

If $\mathrm{Cr}$ is not an essential element for mammals, but at certain dosages modulates glucose and lipids homeostasis, its actions, still not fully understood, could be called "pharmacological."

Among the various chemical forms of $\mathrm{Cr}(\mathrm{III})$ including those used in dietary supplements, the $\mathrm{Cr}(\mathrm{III})$ propionate complex (CrProp) $\left[\mathrm{Cr}_{3} \mathrm{O}\left(\mathrm{O}_{2} \mathrm{CCH}_{2} \mathrm{CH}_{3}\right)_{6}\left(\mathrm{H}_{2} \mathrm{O}\right)_{3}\right]^{+}$, also called $\mathrm{Cr} 3$, is of particular interest. Most results concerning the properties and biological activity of this compound come from Vincent's laboratory [8-10].

In our previous studies [11-13], we showed using various animal models that CrProp, given at dosages of 1 and $5 \mathrm{mg} / \mathrm{kg}$ body mass (b.m.)/day, has a significant insulinsensitizing antidiabetic potential. The therapeutic properties of CrProp in relation to its antidiabetic, insulin-sensitizing potential were discussed in previous publications [9, 11, 12].

The objective of this study was to examine the preventive potential of supplementary CrProp, given at dosages of 10 and $50 \mathrm{mg} \mathrm{Cr} / \mathrm{kg}$ diet, against insulin resistance induced naturally by feeding rats a high-fat diet.

\section{Materials and Methods}

\section{Animals and Diets}

The experiment was carried out according to the Animal Welfare Standards. All the procedures used in this study were accepted by the Animal Bioethics Committee of Poznan, Poland (approval no. 59/2005).

Eight-week-old male Wistar rats $(n=32)$ with body weight ranging from 188 to $248 \mathrm{~g}$ were purchased at the Licensed Laboratory Animal Breeding Center (Poznan, Poland). During both the adaptation and the experimental period, animals were housed under controlled temperature $\left(21 \pm 2{ }^{\circ} \mathrm{C}\right)$, humidity (55-60\%), and with a $12 \mathrm{~h} / 12 \mathrm{~h}$ day/night cycle. After 5 days of the adaptation period, animals were divided into four groups of eight rats each and kept individually in metal-free individual cages. Animals were fed ad libitum standard and high-fat diets composed according to the AIN-93G recommendations [14] of casein (20\%), sunflower oil (7\%), wheat starch $(53.2 \%)$, sucrose $(10 \%)$, potato starch $(5 \%)$, L- cysteine $(0.3 \%)$, vitamin mix AIN-93M (1\%), and mineral mix AIN-93M (3.5\%). The high-fat diets (HF) were obtained from the basal AIN-93 diet, by replacement of wheat starch with fat (up to $25 \%$, approximately $40 \%$ energy from fat). Supplementary $\mathrm{Cr}$ was given in the form of CrProp at dosages of 10 and $50 \mathrm{mg} \mathrm{Cr} / \mathrm{kg}$ diet, so the diets had variable levels of $\mathrm{Cr}$, such as $\mathrm{C}$ (control, $2 \mathrm{mg} \mathrm{Cr} / \mathrm{kg}$ ), $\mathrm{HF}$ (high fat, $2 \mathrm{mg} \mathrm{Cr} / \mathrm{kg}$ ), $\mathrm{HF}+\mathrm{Cr} 10$ (high fat, $10 \mathrm{mg} \mathrm{Cr} / \mathrm{kg}$ ), and $\mathrm{HF}+\mathrm{Cr} 50$ (high fat, $50 \mathrm{mg} \mathrm{Cr} / \mathrm{kg}$ ). Diets were prepared once a week and stored in a refrigerator. Food intake was monitored daily and body mass gain weekly. The chemical composition of experimental diets is presented in Table 1 .

\section{Test Chemicals}

The source of supplemental $\mathrm{Cr}(\mathrm{III})$ was CrProp (chemical formula $\left[\mathrm{Cr}_{3} \mathrm{O}\left(\mathrm{O}_{2} \mathrm{CCH}_{2} \mathrm{CH}_{3}\right)_{6}\left(\mathrm{H}_{2} \mathrm{O}\right)_{3}\right]^{+}\left(\mathrm{NO}_{3}\right)$, called $\left.\mathrm{Cr} 3\right)$, added to the mineral mix to obtain 1,10 , and $50 \mathrm{mg} \mathrm{Cr} / \mathrm{kg}$ diet. The compound was synthesized at the laboratory of the Department of Product Ecology, Poznan University of Economics, according to the method described previously by Earnshaw et al. [15]. The content of $\mathrm{Cr}$ in mineral mix and diets was assured by the atomic absorption spectroscopy (AAS) method (an AAS-3 spectrometer with background correction (BC), Zeiss, Germany). The authenticity was established using the physicochemical characteristics of CrProp as described previously [16]. The addition of CrProp to diets has no impact on feed palatability.

\section{Data Collection}

At the end of the experiment, after 16-h fasting, rats were anesthetized with an intraperitoneal thiopental injection ( $35 \mathrm{mg} / \mathrm{kg} \mathrm{b.m}$.) and dissected to collect blood from the aorta

Table 1 Chemical composition of diets used in experiment (mean \pm SD)

\begin{tabular}{lllll}
\hline Ingredient & \multirow{2}{*}{$\mathrm{C}$} & \multicolumn{2}{l}{ Diets } \\
\cline { 3 - 5 } & & $\mathrm{HF}$ & $\mathrm{HF}+\mathrm{Cr} 10$ & $\mathrm{HF}+\mathrm{Cr} 50$ \\
\hline Energy (MJ, 100 g) & $1.83 \pm 0.01$ & $2.27 \pm 0.02$ & $2.28 \pm 0.03$ & $2.29 \pm 0.02$ \\
Protein (\%) & $18.7 \pm 1.23$ & $17.5 \pm 0.14$ & $17.7 \pm 036$ & $17.9 \pm 0.13$ \\
Fat (\%) & $7.14 \pm 0.31$ & $25.4 \pm 1.07$ & $26.4 \pm 0.21$ & $26.4 \pm 0.08$ \\
Carbohydrates (\%) & 61.7 & 47.9 & 46.9 & 46.2 \\
Dry mass (\%) & $91.8 \pm 0.19$ & $93.7 \pm 0.31$ & $94.0 \pm 0.32$ & $93.5 \pm 0.18$ \\
Ash (\%) & $4.06 \pm 0.71$ & $2.89 \pm 0.23$ & $2.99 \pm 0.11$ & $2.90 \pm 0.12$ \\
Cr ( $\mu \mathrm{g} / \mathrm{g})$ & $2.01 \pm 0.51$ & $2.10 \pm 0.28$ & $10.1 \pm 0.79$ & $50.4 \pm 4.71$ \\
\hline
\end{tabular}

$C$ control (AIN-93G), $H F$ high-fat, $H F+C r 10$ high-fat with $\mathrm{Cr}(10 \mathrm{mg} / \mathrm{kg}$ diet), $H F+C r 50$ high-fat with $\mathrm{Cr}(50 \mathrm{mg} / \mathrm{kg}$ diet $)$ 
and remove inner organs (liver, kidneys, heart, spleen, pancreas, testes) for appropriate biochemical tests. Organs were washed in saline, weighed, and stored at $-20{ }^{\circ} \mathrm{C}$ until analyzed.

\section{Blood Biochemistry}

Blood serum indices were determined by the following methods: glucose concentration by the hexokinase method [17] and total, LDL, and HDL cholesterol contents and triacylglycerol (TAG) concentrations by the colorimetric methods [18-20] using Olympus AU 560 equipment. Plasma insulin concentration was measured by the RIA method using a kit specific for rats (Linco Research, St. Charles, MO, USA).

Activity of alanine transaminase (ALT) and aspartate transaminase (AST) enzymes was measured by the kinetic methods [21], while urea concentration by the kinetic method using urease and glutamine dehydrogenase, and creatinine concentration by Jaffe's kinetic method with picric acid [22]. The total protein concentration was determined by the colorimetric method using $\mathrm{Cu}^{+2}$ ions [23].

The efficacy of glucose utilization and insulin resistance was characterized by the homeostasis model assessment (HOMA) indices [24].

HOMA-IR $=\left(\right.$ Fasting glucose $\left[\mathrm{mmol} / \mathrm{dm}^{3}\right] \times$ Fasting insulin $\left.\left[\mathrm{mIU} / \mathrm{dm}^{3}\right]\right) / 22.5$

\section{Histology of the Liver and the Kidney}

A 3- to 5-mm section of the representative tissue (liver and kidney) was collected at the time of sacrifice and preserved in $10 \%$ buffered formalin. Sections were processed by standard histologic methods and embedded in paraffin. Slices were prepared and stained with hematoxylin and eosin [25].

\section{Microelement Determinations}

Organs were digested in $65 \%(w / w)$ spectra pure $\mathrm{HNO}_{3}$ (Merck) in the Microwave Digestion System (MARS 5, $\mathrm{CEM}$ ). Then, the concentrations of $\mathrm{Fe}, \mathrm{Zn}$, and $\mathrm{Cu}$ in the mineral solutions were measured by the F-AAS method (AAS-3 spectrometer, Zeiss, with BC, Germany), while $\mathrm{Cr}$ content was determined by the graphite furnace AAS method (AA EA 5 spectrometer, with BC, Jenoptic, Germany).

The accuracy of quantitative determinations of $\mathrm{Fe}, \mathrm{Zn}, \mathrm{Cu}$, and $\mathrm{Cr}$ was assured by simultaneous analyses of the certified reference material (Pig Kidney BCR ${ }^{\circledR}$ No. 186, Brussels, fortified with $\mathrm{Cr}$ standard).

\section{Statistical Analysis}

All results are presented as arithmetic means \pm standard deviation, and significance of differences in means was calculated using the one-way ANOVA and Tukey's test. Means were considered statistically different at $p<0.05$. All calculations were made using the STATISTICA (version 7.0) program (StatSoft, Inc., Tulsa).

\section{Results}

General Growth Indices

Feeding rats with high-fat diets resulted in the slightly increasing body weight gain and the significantly increasing body mass/body length ratio (by $10 \%$ ), but it did not affect relative internal organ masses. Generally, supplementary CrProp did not affect overall growth indices in rats fed a high-fat diet; however, in CrProp-supplemented rats, relative liver mass tended to decrease (Table 2).

Insulin Resistance and Lipid Indices

Table 3 presents the effects of high-fat diet and supplementary CrProp on biochemical indices in rats. Feeding rats a high-fat diet (40\% energy from fat) did not affect serum lipid indices or glucose levels, but it induced insulin resistance as evidenced by the twofold increased serum insulin level and homeostasis model assessment-estimated insulin resistance (HOMA-IR) index. Supplementary CrProp (in both dosages) did not influence glucose metabolic indices (glucose, insulin level, and HOMA-IR index) in rats fed high-fat diets. Serum lipid profile was also unchanged, with exception to serum TAG that tended to decrease in CrProp-supplemented groups.

Toxicity Indices and Histology of the Liver and the Kidney

Feeding neither a high-fat diet nor supplementary CrProp (in both dosages) significantly affected indices of liver damage (serum ALT and AST activity) or serum creatinine levels, whereas the high-fat diet significantly decreased serum urea 
Table 2 Effect of CrProp supplementation on overall growth indices in rats (mean \pm SD)

\begin{tabular}{|c|c|c|c|c|}
\hline \multirow[t]{2}{*}{ Index } & \multicolumn{4}{|c|}{ Experimental group } \\
\hline & $\mathrm{C}$ & $\mathrm{HF}$ & $\mathrm{HF}+\mathrm{Cr} 10$ & $\mathrm{HF}+\mathrm{Cr} 50$ \\
\hline Food intake (g/day) & $20.86 \pm 1.59$ & $19.19 \pm 0.49$ & $19.09 \pm 0.49$ & $18.87 \pm 1.74$ \\
\hline Body mass gain $(\mathrm{g}) / 56$ days & $210 \pm 21$ & $245 \pm 29$ & $252 \pm 18$ & $250 \pm 28$ \\
\hline Body mass/body length ratio $(\mathrm{g} / \mathrm{cm})$ & $17.3 \pm 1.23 \mathrm{a}$ & $19.0 \pm 0.91 \mathrm{~b}$ & $18.6 \pm 0.81 \mathrm{~b}$ & $18.3 \pm 1.32 \mathrm{~b}$ \\
\hline Liver (\% b.m.) & $2.86 \pm 0.16$ & $2.99 \pm 0.29$ & $2.88 \pm 0.18$ & $2.80 \pm 0.09$ \\
\hline Kidneys (\% b.m.) & $0.61 \pm 0.07$ & $0.60 \pm 0.07$ & $0.55 \pm 0.03$ & $0.57 \pm 0.03$ \\
\hline Spleen (\% b.m.) & $0.16 \pm 0.02$ & $0.15 \pm 0.02$ & $0.17 \pm 0.02$ & $0.17 \pm 0.03$ \\
\hline Heart (\% b.m.) & $0.29 \pm 0.02$ & $0.29 \pm 0.04$ & $0.32 \pm 0.01$ & $0.30 \pm 0.03$ \\
\hline Testes (\% b.m.) & $0.85 \pm 0.10$ & $0.90 \pm 0.14$ & $0.89 \pm 0.11$ & $0.90 \pm 0.08$ \\
\hline Pancreas (\% b.m.) & $0.33 \pm 0.05$ & $0.32 \pm 0.03$ & $0.33 \pm 0.05$ & $0.37 \pm 0.05$ \\
\hline
\end{tabular}

Means on the same line without a common lowercase letter differ significantly $(p<0.05)$

$C$ control (AIN-93G), $H F$ high-fat fed, $H F+C r 10$ high-fat with $\mathrm{Cr}(10 \mathrm{mg} / \mathrm{kg}$ diet), $H F+C r 50$ high-fat with $\mathrm{Cr}(50 \mathrm{mg} / \mathrm{kg} \mathrm{diet})$

concentration by $16 \%$. Supplementary CrProp did not affect these indices in rats fed high-fat diets (Table 4).

The morphological structures of the liver and the kidney are presented in Figs. 1 and 2. Feeding high-fat diets (40\% energy from fat) led to the accumulation of lipid droplets in hepatocytes but without symptoms of inflammation, necrosis, or sclerotization in the glomerulus.

Neither the interstitium nor glomerulus of the kidney was affected by feeding rats with a high-fat diet. Supplementary CrProp slightly diminished liver lipid accumulation and did not influence kidney morphological structures in rats fed highfat diets.

\section{Tissue Mineral Content}

Feeding rats with a high-fat diet increased renal Fe content and splenic $\mathrm{Cu}$ content by 29 and $16 \%$, respectively, but it did not affect $\mathrm{Zn}$ and $\mathrm{Cr}$ contents in tissues in comparison with the control (Table 5). Supplementary CrProp normalized or even slightly decreased splenic $\mathrm{Cu}$ content, but it did not affect $\mathrm{Fe}$, $\mathrm{Zn}$, or $\mathrm{Cu}$ levels in the other internal organs.
As it could have been expected, supplementary CrProp (10 and $50 \mathrm{mg} \mathrm{Cr} / \mathrm{kg}$ diet), given in 5- and 25-fold higher dosages than the control, increased tissular $\mathrm{Cr}$ contents; in the liver, it increased by 48 and $105 \%$, respectively, while in the kidneys, it increased by 196 and $444 \%$, respectively. The degree of the increase of $\mathrm{Cr}$ content in internal organs was moderate, and kidneys were the main target tissue.

\section{Discussion}

A number of studies both on diabetic animals and diabetic patients reported that $\mathrm{Cr}$ (III) supplementation may be beneficial, as evidenced by a decreased blood glucose, glycosylated hemoglobin, and cholesterol values or decreased insulin requirements after chromium supplementation [11, 13, 26-29]. On the other hand, there are also clinical trials showing that supplementary $\mathrm{Cr}$ (III) did not improve significantly blood biochemistry indices [30-33]. The exact mechanism of $\mathrm{Cr}$ action has not been fully elucidated to date.

Table 3 Effect of high-fat diet and supplemental CrProp on blood serum lipids indices in rats (mean \pm SD)

\begin{tabular}{lllll}
\hline Parameter & \multicolumn{2}{l}{ Experimental group } & & \\
\cline { 2 - 5 } & $\mathrm{C}$ & $\mathrm{HF}$ & $\mathrm{HF}+\mathrm{Cr} 10$ & $\mathrm{HF}+\mathrm{Cr} 50$ \\
\hline Glucose $\left(\mathrm{mmol} / \mathrm{dm}^{3}\right)$ & $8.01 \pm 0.76$ & $8.35 \pm 0.67$ & $8.27 \pm 0.75$ & $8.09 \pm 0.71$ \\
Insulin $\left(\mathrm{mU} / \mathrm{dm}^{3}\right)$ & $29.7 \pm 13.2 \mathrm{a}$ & $59.3 \pm 20.4 \mathrm{~b}$ & $58.9 \pm 16.6 \mathrm{~b}$ & $55.2 \pm 20.8 \mathrm{~b}$ \\
HOMA-IR & $10.6 \pm 4.90 \mathrm{a}$ & $22.3 \pm 8.71 \mathrm{~b}$ & $20.6 \pm 6.62 \mathrm{~b}$ & $20.3 \pm 8.44 \mathrm{~b}$ \\
Total cholesterol $\left(\mathrm{mmol} / \mathrm{dm}^{3}\right)$ & $2.49 \pm 0.33$ & $2.36 \pm 0.24$ & $2.39 \pm 0.28$ & $1.59 \pm 0.17$ \\
HDL cholesterol $\left(\mathrm{mmol} / \mathrm{dm}^{3}\right)$ & $1.69 \pm 0.23$ & $1.64 \pm 0.14$ & $0.38 \pm 0.05$ & $1.52 \pm 0.25$ \\
LDL cholesterol $\left(\mathrm{mmol} / \mathrm{dm}^{3}\right)$ & $0.43 \pm 0.09$ & $0.37 \pm 0.04$ & $1.48 \pm 0.35$ & $0.38 \pm 0.08$ \\
Triacylglycerols $\left(\mathrm{mmol} / \mathrm{dm}^{3}\right)$ & $1.63 \pm 0.11$ & $1.61 \pm 0.68$ & & $1.45 \pm 0.68$ \\
\hline
\end{tabular}

Table notes and abbreviations the same as in Table 2 
Table 4 Effect of high-fat diet and supplemental CrProp on blood toxicity markers in rats (mean $\pm \mathrm{SD})$

\begin{tabular}{llccc}
\hline Blood index & \multicolumn{4}{l}{ Experimental group } \\
\cline { 2 - 5 } & $\mathrm{C}$ & $\mathrm{HF}$ & $\mathrm{HF}+\mathrm{Cr} 10$ & $\mathrm{HF}+\mathrm{Cr} 50$ \\
\hline ALT $\left(\mathrm{U} / \mathrm{dm}^{3}\right)$ & $19.0 \pm 2.32$ & $23.6 \pm 6.32$ & $23.3 \pm 3.41$ & $20.5 \pm 1.91$ \\
AST $\left(\mathrm{U} / \mathrm{dm}^{3}\right)$ & $97.3 \pm 12.7$ & $100.2 \pm 15.9$ & $107.0 \pm 9.9$ & $98.3 \pm 10.8$ \\
$\begin{array}{c}\text { Total protein } \\
\left(10^{-2} \mathrm{~kg} / \mathrm{dm}^{3}\right)\end{array}$ & $6.44 \pm 0.37$ & $6.38 \pm 0.29$ & $6.17 \pm 0.15$ & $6.15 \pm 0.20$ \\
$\begin{array}{c}\text { Creatinine } \\
\left(\mu \mathrm{mol} / \mathrm{dm}^{3}\right)\end{array}$ & $36.2 \pm 3.52$ & $36.2 \pm 3.51$ & $35.4 \pm 0$ & $36.2 \pm 3.54$ \\
Urea $\left(\mathrm{mmol} / \mathrm{dm}^{3}\right)$ & $5.63 \pm 0.77$ & $4.75 \pm 0.93$ & $4.25 \pm 0.37$ & $4.39 \pm 0.52$ \\
\hline
\end{tabular}

Abbreviations the same as in Table 2

It is believed that the efficiency of supplementary $\mathrm{Cr}$ in the regulation of disturbed glucose and lipid metabolism depends on various factors, such as the chemical form and dose of $\mathrm{Cr}$ (and its bioavailability), the degree of insulin resistance or hyperglycemia, and individual sensitivity and genetics, which are not fully defined factors.

The chromium(III) propionate complex (CrProp) was found to be a promising insulin-activating agent, due to its high stability and solubility in the physiological milieu and high absorption rate reaching up to $40-60 \%$ [8]. In a previous study by a team of Vincent and coworkers [10], this compound given to rats showed insulin-sensitizing properties. Lower dosages of CrProp (20 $\mu \mathrm{g} / \mathrm{kg} \mathrm{b}$.m./day) after a 12 week administration resulted in lowering of blood plasma LDL, total, and HDL cholesterol levels and triglyceride levels in rats. In another study performed by that team [34], Zucker
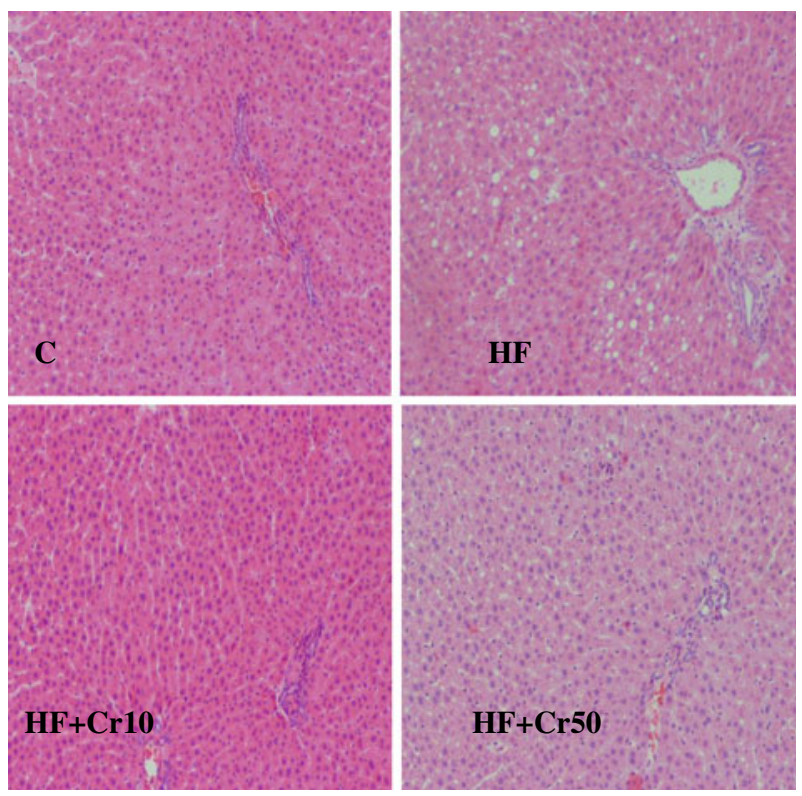

Fig. 1 Histopathological images of rats' livers $($ zoom $\times 750)$ : C - control group, $\mathrm{HF}$ - group fed high-fat diet, $\mathrm{HF}+\mathrm{Cr} 10$ - group fed high-fat diet supplemented with $10 \mathrm{mg} \mathrm{Cr} / \mathrm{kg}$ diet, and $\mathrm{HF}+\mathrm{Cr} 50$ - group fed high-fat diet supplemented with $50 \mathrm{mg} \mathrm{Cr} / \mathrm{kg}$ diet

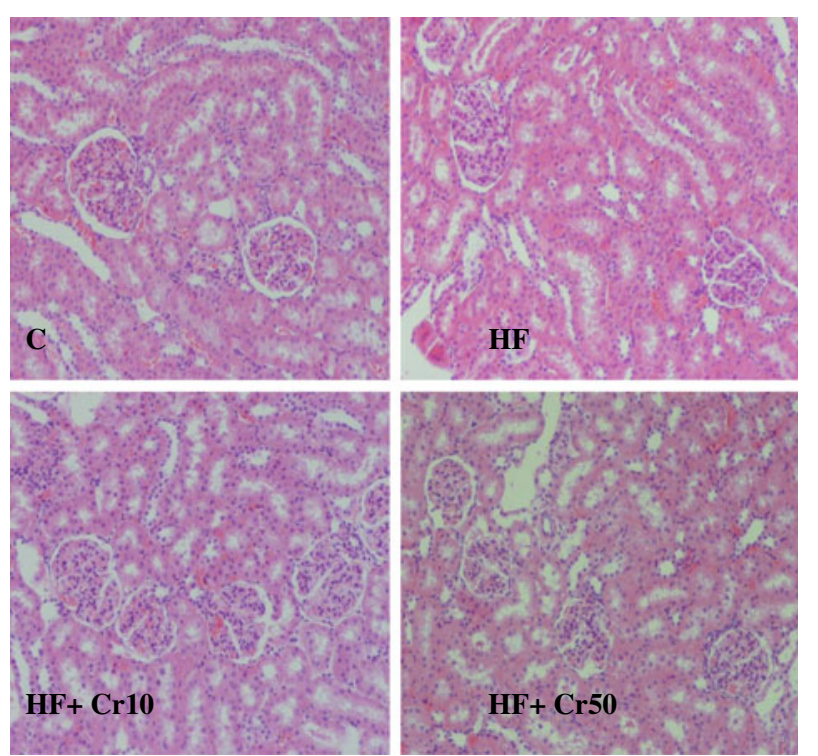

Fig. 2 Histopathological images of rats' kidney (zoom $\times 750)$ : C - control group, $\mathrm{HF}$ - group fed high-fat diet, $\mathrm{HF}+\mathrm{Cr} 10$ - group fed high-fat diet supplemented with $10 \mathrm{mg} \mathrm{Cr} / \mathrm{kg}$ diet, and $\mathrm{HF}+\mathrm{Cr} 50$ - group fed high-fat diet supplemented with $50 \mathrm{mg} \mathrm{Cr} / \mathrm{kg}$ diet

obese rats (a model of the early stages of type 2 diabetes), CrProp lowered fasting plasma total, HDL, and LDL cholesterol, triglyceride concentrations, as well as insulin levels, and it lowered 2-h plasma insulin levels after 24 weeks of administration. On the other hand, this compound had little effect on rats with streptozotocin (STZ)-induced diabetes (a type 1 diabetes model). These results were further confirmed by Clodfelder et al. [9], who applied higher dosages of CrProp (up to $1,000 \mu \mathrm{g} \mathrm{Cr} / \mathrm{kg} \mathrm{b.m./day)} \mathrm{in} \mathrm{healthy} \mathrm{and} \mathrm{type} 2$ diabetic rats. It is worth noting that this study was conducted on rats, where the metabolic changes associated with diabetes were induced pharmacologically or by genetic engineering. In those models, hyperglycemia and insulin resistance were more pronounced; thus, the effects of CrProp were also more pronounced.

In this study, we tested the preventive potential of supplementary $\mathrm{Cr}$, given in the form of CrProp, against insulin resistance in Wistar rats. There are different ways of inducing insulin resistance and diabetes in experimental animals, including genetic modification (e.g., obese animals), pharmacologic intervention (e.g., STZ and alloxan injection), dietary manipulation (e.g., high-fat and high-fructose diets), and their combinations (e.g., high-fat feeding and STZ injection). Some studies [35] showed that a high-fat diet $(\sim 65 \%$ calories from fat) is more effective than a high-fructose $\operatorname{diet}(\sim 65 \%$ calories from fructose) in inducing insulin resistance in Wistar rats.

The impact of different fat types on glucose and lipidrelated parameters was excessively studied by Buetner et al. [36]. Those authors confirmed that the rats administered a 12week lard-based high-fat diet (approximately $42 \%$ energy from fat) gave symptoms resembling the human metabolic 
Table 5 Effect of high-fat diet and supplemental CrProp on the tissular iron, zinc, copper, and chromium levels in rats (mean \pm SD)

\begin{tabular}{|c|c|c|c|c|}
\hline \multirow[t]{2}{*}{ Index } & \multicolumn{4}{|c|}{ Experimental group } \\
\hline & $\mathrm{C}$ & $\mathrm{HF}$ & $\mathrm{HF}+\mathrm{Cr} 10$ & $\mathrm{HF}+\mathrm{Cr} 50$ \\
\hline \multicolumn{5}{|c|}{$\mathrm{Fe}(\mu \mathrm{g} / \mathrm{g}$ dry matter (d.m.)) } \\
\hline Liver & $359 \pm 43.1$ & $372 \pm 53.3$ & $339 \pm 47.4$ & $393 \pm 61.0$ \\
\hline Kidney & $280 \pm 40.1 \mathrm{a}$ & $360 \pm 49.01 \mathrm{~b}$ & $379 \pm 35.2 \mathrm{~b}$ & $363 \pm 39.1 \mathrm{~b}$ \\
\hline Spleen & $2,560 \pm 517$ & $2,551 \pm 538$ & $2,597 \pm 198$ & $2,765 \pm 594$ \\
\hline \multicolumn{5}{|c|}{$\mathrm{Zn}(\mu \mathrm{g} / \mathrm{g}$ d.m. $)$} \\
\hline Liver & $90.1 \pm 4.25$ & $96.6 \pm 8.12$ & $90.2 \pm 9.23$ & $96.9 \pm 6.03$ \\
\hline Kidney & $86.7 \pm 3.55$ & $92.2 \pm 5.91$ & $93.8 \pm 7.65$ & $96.1 \pm 6.47$ \\
\hline Spleen & $41.37 \pm 4.26$ & $41.45 \pm 7.24$ & $46.04 \pm 3.02$ & $48.05 \pm 4.08$ \\
\hline \multicolumn{5}{|c|}{$\mathrm{Cu}(\mu \mathrm{g} / \mathrm{g}$ d.m. $)$} \\
\hline Liver & $15.3 \pm 2.91$ & $15.8 \pm 0.63$ & $13.7 \pm 1.45$ & $15.9 \pm 0.81$ \\
\hline Kidney & $20.1 \pm 2.13$ & $24.6 \pm 4.32$ & $24.6 \pm 4.78$ & $24.4 \pm 4.23$ \\
\hline Spleen & $8.35 \pm 2.79 \mathrm{a}$ & $9.67 \pm 3.25 b$ & $6.01 \pm 0.95 \mathrm{a}$ & $6.06 \pm 1.00 \mathrm{a}$ \\
\hline \multicolumn{5}{|c|}{$\mathrm{Cr}(\mu \mathrm{g} / \mathrm{g}$ d.m. $)$} \\
\hline Liver & $0.62 \pm 0.18 \mathrm{a}$ & $0.58 \pm 0.21 \mathrm{a}$ & $0.92 \pm 0.53 \mathrm{ab}$ & $1.19 \pm 0.64 \mathrm{~b}$ \\
\hline Kidney & $0.46 \pm 0.17 \mathrm{a}$ & $0.52 \pm 0.23 \mathrm{a}$ & $1.54 \pm 0.7 \mathrm{~b}$ & $2.83 \pm 0.58 \mathrm{c}$ \\
\hline
\end{tabular}

Table notes and abbreviations the same as in Table 2

syndrome, i.e., obesity, adiposity, an increased insulin resistance index (HOMA-IR), or decreased serum adiponectin levels, but not inflammation. Another way of inducing insulin resistance is feeding animals a high-fructose $\operatorname{diet}$ (up to $60 \%$ ), which leads to increased adiposity and free fatty acid contents in adipose tissues [37], hypertension, oxidative stress, increased hydrogen peroxide generation, and inflammation [38-40]. Generally, both animal models of insulin resistance appear to be suitable for testing insulin-sensitizing agents.

In the present study, we used a high-fat diet to induce insulin resistance in rats. There are significant differences in lipid metabolism in rats and humans. These rodents show higher tolerance to excessive fat consumption in comparison to human subjects; however, this method seems more natural in mimicking the process that occurs in humans than the pharmacologic intervention.

Forbes et al. [41] investigated the effect of different diets, which could be classified as Western diets, on insulin resistance. It was found that excessive consumption of saturated animal origin fat increased body mass and adiposity, decreased insulin sensitivity, and impaired skeletal muscle insulin signaling and insulin hypersecretion. The observed effect depends not only on the total amount of fat, but first of all, on the fatty acid composition of dietary components [36]. Highfat diet induces liver steatosis and disturbs iron metabolism in rats [42].

In the last few years, several publications appeared regarding the influence of supplementation with $\mathrm{Cr}(\mathrm{III})$ compounds on high-fat-fed animals. For example, Sahin et al. [43] compared the effects of two $\mathrm{Cr}$ (III) compounds, i.e., Cr glycinate (CrGly) and $\mathrm{Cr}$ acetate (CrAc), given at dosages of 4 and $8 \mu \mathrm{g} / \mathrm{kg}$ b.m./ day on Wistar rats fed high-fat diets. It was found that animals receiving CrGly had greater serum insulin concentrations (by $3.0 \%$ ), while those treated with CrAc had lower serum glucose concentrations (by $1.7 \%$ ) as well as the glucose/insulin ratio (by $4.49 \%$ ). Similar results were observed for $\mathrm{Cr}(\mathrm{III})$ histidinate (CrHis) [44].

Kandadi et al. [45] reported that supplementary chromium (D-phenylalanine) $)_{3}(45 \mu \mathrm{g} \mathrm{Cr} / \mathrm{kg}$ b.m./day) had no effect on food intake and body and organ masses, but it normalized serum glucose, insulin, and triglyceride levels in C57BL/6 mice fed high-fat diets.

Chen et al. [46] studied the effect of supplementary Crcontaining milk concentrate capsule $(80 \mu \mathrm{g} / \mathrm{kg} \mathrm{b.m./day)} \mathrm{and}$ high-fat diets (67\% of calories provided by fat) on KK/ HIJ mice. It was found that supplementary $\mathrm{Cr}$ reduced the hepatic triglyceride accumulation, elevated hepatic lipid catabolic enzymes, improved liver histopathological changes, and suppressed inflammation as well as oxidative stress. Similar improvements in liver histology were also observed by Sahin et al. [47] in high-fat diet fed/STZ-injected Sprague-Dawley rats supplemented with $\mathrm{Cr}(\mathrm{III})$ picolinate $(80 \mu \mathrm{g} / \mathrm{kg}$ b.m.). In this study, CrProp supplementation tended to decrease relative liver mass and serum triglyceride concentration and slightly improved liver histopathological changes caused by high-fat feeding. These results suggest that this compound slightly inhibits the liver steatosis; however, the liver triglyceride content was not determined, and therefore, it needs to be confirmed in a further study. 
In our previous studies [11, 12], insulin resistance was induced by feeding rats for 8 weeks a high-fructose diet (60\% fructose $\mathrm{w} / \mathrm{w})$ and a high-fat diet (40\% calories) and by STZ injection ( $35 \mathrm{mg} / \mathrm{kg}$ b.m.). However, these models gave different degrees of metabolic changes in terms of insulin resistance and related effects in rats.

In particular, the first treatment induced insulin resistance without hyperglycemia (HOMA-IR index increased by $230 \%$, with only a slight increase of serum glucose by $16 \%$ ), while the latter model resulted in insulin resistance (HOMA-IR index increased by $130 \%$ ) with hyperglycemia (serum glucose increased by $170 \%$ ). The therapeutic potential of CrProp, given at the dosages of 1 and $5 \mathrm{mg} \mathrm{Cr} / \mathrm{kg} \mathrm{b.m./day,}$ was then tested on those models. It was found that in highfructose-fed rats, supplementary CrProp in both dosages was able to significantly decrease serum insulin levels and insulin resistance indexes HOMA-IR and HOMA-B, while it increased the QUICKI insulin sensitivity index. Also, in highfat/STZ rats, CrProp, especially given in a higher dosage, was more effective in improving those indices. The efficiency of supplementary $\mathrm{Cr}$ depended, among other factors, on the degree of metabolic disturbances occurring in the organism, in the following mode: the higher the degree of insulin resistance or hyperglycemia, the stronger the effect of $\mathrm{Cr}$, which suggests its pharmacological action.

This statement falls in agreement with the observations that supplementary $\mathrm{Cr}$, no matter what chemical form or dosage is applied, has no effect on a healthy organism, both in animals and humans. Recently, Herring et al. [48] studied the same $\mathrm{Cr}$ compound ( $\mathrm{Cr} 3$ or CrProp) in healthy rats fed cafeteria-style diets (high-fat and high-carbohydrate diets) in a long exposure experiment. After a 15 -month feeding of rats using those diets, CrProp at a dosage of $1 \mathrm{mg} / \mathrm{kg}$ b.m./day had no effect on body mass, organ masses (liver, kidneys, lungs, and heart), or visceral fat mass. In the present study, the calculated average daily $\mathrm{Cr}$ intake in experimental CrProp-supplemented groups was 0.58 and $2.85 \mathrm{mg} \mathrm{Cr} / \mathrm{kg} \mathrm{b.m./day,} \mathrm{respectively} \mathrm{(based} \mathrm{on}$ the daily food intake, analyzed $\mathrm{Cr}$ content in the diet, and weekly body gain).

$\mathrm{Cr}$ in its trivalent form can interact in vivo with other essential elements, especially with $\mathrm{Fe}$. The $\mathrm{Fe}-\mathrm{Cr}$ interaction may occur, since these elements have the same transport protein, transferrin. The relationship between an increased dietary $\mathrm{Cr}$ (III) intake and $\mathrm{Fe}$ stores was confirmed in several studies. For example, in our previous study, 8-week CrProp supplementation ( $1 \mathrm{mg} \mathrm{Cr} / \mathrm{kg}$ b.m./day) decreased Fe kidney concentration [11]; in contrast, a 4-week administration of CrProp in the same dosages did not influence the examined parameters of iron status in rats fed a high-fructose diet [49]. In obese type 2 diabetic rats, supplementation of $1,000 \mu \mathrm{g} \mathrm{Cr} /$ $\mathrm{kg}$ b.m./day in the form of CrProp reduced kidney Fe level [12]. Consistent results were observed for the same dosages used in another experiment, where CrProp normalized an increased liver Fe content in rats fed high-fat diets/STZinjected rats [12]. On the other hand, another $\mathrm{Cr}$ complex, CrHis, did not change tissular Fe concentration in a similar animal model of type 2 diabetes after 10 weeks of supplementation [50].

The effects of different $\mathrm{Cr}$ compounds on mineral metabolism have been extensively investigated by Staniek et al. [51]. In that comparative study, supplementary $\mathrm{Cr}$

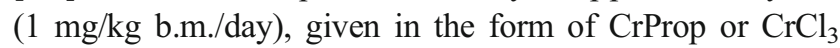
for 12 weeks, significantly increased $\mathrm{Cr}$ accumulation in kidneys of lean and obese but not Zucker diabetic rats. Generally, there were no changes in tissular contents of $\mathrm{Ca}, \mathrm{Mg}$, $\mathrm{Fe}$, and $\mathrm{Zn}$, except for $\mathrm{Cu}$, in rats.

Similarly, supplementary CrProp affected $\mathrm{Cu}$ levels in rats fed a high-fructose diet for 4 or 8 weeks. In particular, this compound normalized elevated liver and splenic $\mathrm{Cu}$ contents $[11,49]$, while it decreased hepatic and renal $\mathrm{Cu}$ levels in diabetic rats [12].

In conclusion, this study showed that supplementary CrProp, given in the dosages of 10 and $50 \mathrm{mg} \mathrm{Cr} / \mathrm{kg}$ diet (approximately 0.6 and $3 \mathrm{mg} \mathrm{Cr} / \mathrm{kg} \mathrm{b.m./day,} \mathrm{respectively),} \mathrm{is}$ not able to prevent insulin resistance induced by feeding rats with a high-fat diet.

Acknowledgments The project was supported partly by individual research grant $(242 / \mathrm{TZ} / 86 / \mathrm{W})$. The authors would like to thank Ms. Małgorzata Tubacka for the help given during the animal experiment.

Conflict of Interest The authors declare that there are no conflicts of interest.

Open Access This article is distributed under the terms of the Creative Commons Attribution License which permits any use, distribution, and reproduction in any medium, provided the original author(s) and the source are credited.

\section{References}

1. Whiting DR, Guariguata L, Weil C, Shaw J (2011) IDF diabetes atlas: global estimates of the prevalence of diabetes for 2011 and 2030. Diabetes Res Clin Pract 94(3):311-321

2. Muoio DM, Newgard CB (2008) Mechanisms of disease: molecular and metabolic mechanisms of insulin resistance and beta-cell failure in type 2 diabetes. Nat Rev Mol Cell Biol 9:193-205

3. Gillies CL, Abrams KR, Lambert PC, Cooper NJ, Sutton AJ, Hsu RT, Khunti K (2007) Pharmacological and lifestyle interventions to prevent or delay type 2 diabetes in people with impaired glucose tolerance: systematic review and meta-analysis. BMJ 334:299

4. Stallings D, Vincent JB (2006) Chromium. A case study in how not to perform nutritional research. Curr Topics Nutraceut Res 4:89-112

5. DiBona KR, Love S, Rhodes NR, McAdory D, Sinha SH, Kern N, Kent J, Strickland J, Wilson A, Beaird J, Ramage J, Rasco JF, Vincent JB (2011) Chromium is not an essential trace element for mammals: effects of a "low-chromium" diet. J Biol Inorg Chem 16:381-390

6. Vincent JB (2010) Chromium: celebrating 50 years as an essential element? Dalton Trans 39:3787-3794 
7. Vincent JB, Love ST (2012) The need for combined inorganic, biochemical, and nutritional studies of chromium(III). Chem Biodivers 9:1923-1940

8. Clodfelder BJ, Chang C, Vincent JB (2004) Absorption of the biomimetic chromium cation triaqua-1-oxo-hexapropionatotrichromium(III) in rats. Biol Trace Elem Res 98:159-169

9. Clodfelder BJ, Gullick BM, Lukaski HC, Neggers Y, Vincent JB (2005) Oral administration of the biomimetic $\left[\mathrm{Cr}_{3} \mathrm{O}\left(\mathrm{O}_{2} \mathrm{CCH}_{2} \mathrm{CH}_{3}\right)_{6}\left(\mathrm{H}_{2} \mathrm{O}\right)_{3}\right]^{+}$ increases insulin sensitivity and improves blood plasma variables in healthy and type 2 diabetic rats. J Biol Inorg Chem 10:119-130

10. Sun Y, Clodfelder BJ, Shute AA, Irvin T, Vincent JB (2002) The biomimetic $\left[\mathrm{Cr}_{3} \mathrm{O}\left(\mathrm{O}_{2} \mathrm{CCH}_{2} \mathrm{CH}_{3}\right)_{6}\left(\mathrm{H}_{2} \mathrm{O}\right)_{3}\right]^{+}$decreases plasma insulin, cholesterol, and triglycerides in healthy and type II diabetic rats but not type I diabetic rats. J Biol Inorg Chem $7: 852-862$

11. Król E, Krejpcio Z (2010) Chromium(III) propionate complex supplementation improves carbohydrate metabolism in insulinresistance rat model. Food Chem Toxicol 48:2791-2796

12. Król E, Krejpcio Z (2011) Evaluation of anti-diabetic potential of chromium(III) propionate complex in high-fat diet fed and STZ injected rats. Food Chem Toxicol 49(12):3217-3223

13. Król E, Krejpcio Z, Michalak S, Wójciak RW, Bogdański P (2012) Effects of combined dietary chromium(III) propionate complex and thiamine supplementation on insulin sensitivity, blood biochemical indices, and mineral levels in high-fructose-fed rats. Biol Trace Elem Res 150(1-3):350-359

14. Reeves PG, Nielsen FH, Fahey GC Jr (1993) AIN-93 purified diets for laboratory rodents: final report of the American Institute of Nutrition ad hoc writing committee on the reformulation of the AIN-76A rodent diet. J Nutr 123:1939-1951

15. Earnshaw A, Figgis BN, Lewis J (1966) Chemistry of polynuclear compounds. Part VI. Magnetic properties of trimeric chromium and iron carboxylates. J Chem Soc A 1656-1663

16. Wieloch A, Wieczorek D, Staniek H, Szymusiak H, Krejpcio Z, Zieliński R (2007) Tricentric complexes of chromium(III) with glycine and serine ligands. Curr Trends Commod Sci II: 1080-1086

17. Sacks DB, Bruns DE, Goldstein DE, Maclaren NK, McDonald JM, Parrott M (2002) Guidelines and recommendations for laboratory analysis in the diagnosis and management of diabetes mellitus. Clin Chem 48:436-472

18. Miki Y (1999) A homogenous assay for the selective measurement of LDL-cholesterol in serum. Enzymatic selective protection method. Clin Lab 45:398-401

19. Riesen WF (1998) Lipid metabolism. In: Thomas L (ed) Clinical laboratory diagnostics. Use and assessment of clinical laboratory results. TH-Books Verlagsgesellschaft, Frankfurt Main

20. Shephard MD, Whiting MJ (1990) Falsely low estimation of triglycerides in lipemic plasma by the enzymatic triglyceride method with modified Trinder's chromogen. Clin Chem 36:325-329

21. Schumann G, Klauke R (2003) New IFCC reference procedures for the determination of catalytic activity concentrations of five enzymes in serum: preliminary upper reference limits obtained in hospitalized subjects. Clin Chim Acta 327:69-79

22. Newmann DJ, Price CP (1999) Renal function and nitrogen metabolites. In: Burtis CA, Ashwood ER (eds) Tietz book of clinical chemistry. Saunders, Philadelphia, pp 1239-1242

23. Thomas L (1998) Total protein. In: Thomas L (ed) Clinical laboratory diagnostics. Use and assessment of clinical laboratory results. THBooks Verlagsgesellschaft, FrankfuntMain, pp 644-647

24. Matthews DR, Hosker JP, Rudenski AS, Naylor BA, Treacher DF, Turner RC (1985) Homeostasis model assessment: insulin resistance and beta-cell function from fasting plasma glucose and insulin concentrations in man. Diabetologia 28:412-419

25. Zawistowski S (1983) Technika histologiczna: histologia oraz podstawy histopatologii. PZWL, Warszawa (in polish)
26. Cefalu WT, Hu FB (2004) Role of chromium in human health and in diabetes. Diabetes Care 27:2741-2751

27. Anderson RA, Cheng N, Bryden NA, Polansky MM, Cheng N, Chi J, Feng J (1997) Elevated intakes of supplemental chromium improve glucose and insulin variables in individuals with type 2 diabetes. Diabetes 46:1786-1791

28. Lee NA, Reasner CA (1994) Beneficial effect of chromium supplementation on serum triglyceride levels in NIDDM. Diabetes Care 17: $1449-1452$

29. Cheng N, Zhu X, Shi H, Wu W, Chi J, Cheng J, Anderson RA (1999) Follow-up survey of people in China with type 2 diabetes mellitus consuming supplemental chromium. J Trace Elem Exp Med 12:5560

30. Król E, Krejpcio Z, Byks H, Bogdański P, Pupek-Musialik D (2011) Effects of chromium brewer's yeast supplementation on body mass, blood carbohydrates, and lipids and minerals in type 2 diabetic patients. Biol Trace Elem Res 143(2):726-737

31. Gunton JE, Cheung NW, Hitchman R, Hams G, O'Sullivan C, FosterPowell K, McElduff A (2005) Chromium supplementation does not improve glucose tolerance, insulin sensitivity, or lipid profile: a randomized, placebo-controlled, double-blind trial of supplementation in subjects with impaired glucose tolerance. Diabetes Care 28: $712-713$

32. Iqbal N, Cardillo S, Volger S, Bloedon LT, Anderson RA, Boston R, Szapary PO (2009) Chromium picolinate does not improve key features of metabolic syndrome in obese nondiabetic adults. Metab Syndr Relat Disord 7:143-150

33. Kleefstra N, Houweling S, Jansman FGA, Groenier KH, Gans ROB, Mayboom-de Jong B, Bakker SJ, Bilo HJ (2006) Chromium treatment has no effect in patients with poorly controlled, insulin-treated type 2 diabetes in an obese Western population: a randomized, double-blind, placebo-controlled trial. Diabetes Care 29:521-525

34. Sun Y, Mallya K, Ramirez J, Vincent JB (1999) The biomimetic $\left[\mathrm{Cr}_{3} \mathrm{O}\left(\mathrm{O}_{2} \mathrm{CCH}_{2} \mathrm{CH}_{3}\right)_{6}\left(\mathrm{H}_{2} \mathrm{O}\right)_{3}\right]^{+}$decreases plasma cholesterol and triglycerides in rats: towards chromium-containing therapeutics. J Inorg Biochem 4:838-845

35. Zaman MQ, Leray V, Le Bloc'h J, Thorin C, Ouguerram K, Nguyen $P$ (2011) Lipid profile and insulin sensitivity in rats fed with high-fat or high-fructose diets. Br J Nutr 106(Suppl 1):S206-210

36. Buettner R, Parhofer KG, Woenckhaus M, Wrede CE, KunzSchughart LA, Schölmerich J, Bollheimer LC (2006) Defining high-fat-diet rat models: metabolic and molecular effects of different fat types. J Mol Endocrinol 36(3):485-501

37. Rutledge AC, Adeli K (2007) Fructose and the metabolic syndrome: pathophysiology and molecular mechanisms. Nutr Rev 65:13-23

38. Dekker MJ, Su Q, Baker C, Rutledge AC, Adeli K (2010) Fructose: a highly lipogenic nutrient implicated in insulin resistance, hepatic steatosis, and the metabolic syndrome. Am J Physiol Endocrinol Metab 299(5):E685-694

39. Miller A, Adeli K (2008) Dietary fructose and the metabolic syndrome. Curr Opin Gastroenterol 24(2):204-209

40. Nyby MD, Abedi K, Smutko V, Eslami P, Tuck ML (2007) Vascular angiotensin type 1 receptor expression is associated with vascular dysfunction, oxidative stress and inflammation in fructose-fed rats. Hypertens Res 30(5):451-457

41. Forbes JM, Cowan SP, Andrikopoulos S, Morley AL, Ward LC, Walker KZ, Cooper ME, Coughlan MT (2013) Glucose homeostasis can be differentially modulated by varying individual components of a western diet. J Nutr Biochem 24(7):1251-1257

42. Meli R, Mattace Raso G, Irace C, Simeoli R, Di Pascale A, Paciello O, Pagano TB, Calignano A, Colonna A, Santamaria R (2013) High fat diet induces liver steatosis and early dysregulation of iron metabolism in rats. PLoS One 8(6):e66570

43. Sahin K, Tuzcu M, Orhan C, Agca CA, Sahin N, Guvenc M, Krejpcio Z, Staniek H, Hayirli A (2011) The effects of chromium 
complex and level on glucose metabolism and memory acquisition in rats fed high-fat diet. Biol Trace Elem Res 143(2):1018-1030

44. Tuzcu M, Sahin N, Orhan C, Agca CA, Akdemir F, Tuzcu Z, Komorowski J, Sahin K (2011) Impact of chromium histidinate on high fat diet induced obesity in rats. Nutr Metab (Lond) 8:28

45. Kandadi MR, Unnikrishnan MK, Warrier AK, Du M, Ren J, Sreejayan N (2011) Chromium (D-phenylalanine)3 alleviates high fat-induced insulin resistance and lipid abnormalities. J Inorg Biochem 105(1):58-62

46. Chen WY, Chen CJ, Liu CH, Mao FC (2010) Chromium attenuates high-fat diet-induced nonalcoholic fatty liver disease in KK/HIJ mice. Biochem Biophys Res Commun 397(3): 459-464

47. Sahin K, Onderci M, Tuzcu M, Ustundag B, Cikim G, Ozercan IH, Sriramoju V, Juturu V, Komorowski JR (2007) Effect of chromium on carbohydrate and lipid metabolism in a rat model of type 2 diabetes mellitus: the fat-fed, streptozotocin-treated rat. Metab Clin Exp 56:1233-1240
48. Herring BJ, Logsdon AL, Lockard JE, Miller BM, Kim H, Calderon EA, Vincent JB, Bailey MM (2013) Long-term exposure to $\left.\left.\left.\left.\left[\mathrm{Cr}\left({ }_{3}\right) \mathrm{O}\left(\mathrm{O}_{2}\right) \mathrm{CCH}_{2}\right) \mathrm{CH}_{3}\right)\right)\left({ }_{6}\right)\left(\mathrm{H}_{2}\right) \mathrm{O}\right)\left(_{3}\right)\right](+)$ in Wistar rats fed normal or high-fat diets does not alter glucose metabolism. Biol Trace Elem Res 151(3):406-414

49. Król E, Krejpcio Z (2013) Dietary chromium(III) propionate complex supplementation affects tissue mineral levels in rats fed highfructose diet. J Elem 18(1):91-98

50. Dogukan A, Sahin N, Tuzcu M, Juturu V, Orhan C, Onderci M, Komorowski J, Sahin K (2009) The effects of chromium histidinate on mineral status of serum and tissue in fat-fed and streptozotocin-treated type II diabetic rats. Biol Trace Elem Res 131:124-132

51. Staniek H, Rhodes NR, Di Bona KR, Deng G, Love ST, Pledger LA, Blount J, Gomberg E, Grappe F, Cernosek C, Peoples B, Rasco JF, Krejpcio Z, Vincent JB (2013) Comparison of tissue metal concentrations in Zucker lean, Zucker obese, and Zucker diabetic fatty rats and the effects of chromium supplementation on tissue metal concentrations. Biol Trace Elem Res 151(3):373-383 